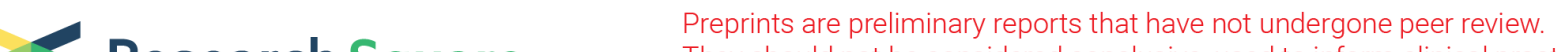 $\begin{array}{ll}\text { Research Square } & \begin{array}{l}\text { They should not be considered conclusive, used to inform clinical practice, } \\ \text { or referenced by the media as validated information. }\end{array}\end{array}$
}

\section{DNA damage in cumulus cells generated after the vitrification of in vitro matured porcine oocytes and its impact on fertilization and embryo development}

\section{Alma López}

Universidad Autonoma Metropolitana Iztapalapa

Miguel Betancourt

Universidad Autonoma Metropolitana Iztapalapa

\section{Yvonne Ducolomb}

Universidad Autonoma Metropolitana Iztapalapa

Juan José Rodríguez

Universidad Nacional Autónoma de México: Universidad Nacional Autonoma de Mexico

\section{Eduardo Casas}

Universidad Autonoma Metropolitana Iztapalapa

Edmundo Bonilla

Universidad Autonoma Metropolitana Iztapalapa

Iván Bahena

Universidad Autonoma Metropolitana Iztapalapa

\section{Socorro Retana-Márquez}

Universidad Autonoma Metropolitana Iztapalapa

\section{Lizbeth Juárez-Rojas}

Universidad Autonoma Metropolitana Iztapalapa

Fahiel Casillas ( $\sim$ fahiel@xanum.uam.mx )

Universidad Autonoma Metropolitana Iztapalapa https://orcid.org/0000-0002-9916-0586

\section{Research Article}

Keywords: Vitrification, matured oocytes, cumulus cells, DNA damage, cryoprotectants, porcine

Posted Date: April 21st, 2021

DOl: https://doi.org/10.21203/rs.3.rs-441164/v1

License: (c) (1) This work is licensed under a Creative Commons Attribution 4.0 International License.

Read Full License 


\section{Abstract}

Oocyte vitrification has become an important tool for the improvement of assisted reproduction in humans and other mammalian species. The toxicity and use of high cryoprotectants concentrations have been a limiting factor for cryopreservation success. The evaluation of the DNA damage generated in cumulus cells after mature cumulus-oocyte complexes vitrification can be considered as an indicator of oocyte quality since these cells play important roles in oocyte developmental competence. Alterations produced in these cells could compromise oocyte maturation, fertilization, and embryo development. Therefore, the aim of this study was to determine if matured cumulus-oocyte complexes exposure to cryoprotectants or vitrification affects both oocytes and cumulus cells viability, but also if DNA damage is generated in cumulus cells, affecting fertilization and embryo development. The DNA damage in cumulus cells was measured using the alkaline comet assay and expressed as Comet Tail Length and Olive Tail Moment. Results demonstrate that oocyte exposure to cryoprotectants or vitrification reduced oocyte and cumulus cells viability compared to control. Also, significantly higher DNA damage was generated in the cumulus cells after exposure to cryoprotectants and vitrification compared to control. In addition, fertilization and embryo development rates also decreased after exposure to cryoprotectants and vitrification. It was also found that fertilization and embryo development rates in granulose-intact oocytes were significantly higher compared to denuded oocytes in the control groups. However, a decline in oocyte fertilization and embryo development to the blastocyst stage was observed after cryoprotectants exposure or vitrification. This could be attributed to the reduction in both cell types viability, and the generation of DNA damage in the cumulus cells. These findings will allow to understand some of the mechanisms of oocyte damage after vitrification, and the search for new vitrification strategies to increase fertilization and embryo development rates.

\section{Introduction}

Oocyte vitrification has become an important tool for the improvement of assisted reproduction in humans and other mammalian species. The oocyte meiotic stage [1], the cryoprotectant agents (CPAs) selection, and the volume of the cell-storage device [2] are key factors associated with the success of vitrification. For vitrification, CPAs are used at high concentrations (16-50\%), which causes detrimental effects in oocytes and compromises their further development. The toxicity and use of high CPAs concentrations have been a limiting factor for cryopreservation success. For this reason, new vitrification strategies such as cryoprotectant-free vitrification methods have been developed for use with human spermatozoa [3] and equine oocytes [4]. However, this has not been reported in porcine oocytes, so that the use of CPAs is still required [5]. For oocyte cryopreservation, ethylene glycol (EG) and dimethylsulfoxide (DMSO) have been the most widely used permeable CPAs. It was reported that its use is safer than 1,2- propanediol (PROH) [6]. Somfai et al. (2015) [2] reported that the mixture of EG + propylene glycol $(\mathrm{PG})$ is similar to $E G+D M S O$ in blastocyst production after immature oocyte vitrification. Also, we reported that immature oocyte vitrification with EG + DMSO resulted in a $30 \%$ 
blastocyst formation [7]. Therefore, in the present study, EG + DMSO were used for metaphase II (MII) oocytes exposure or vitrification.

In humans and other mammalian species, oocytes are mostly recovered and vitrified at the MII stage $[8,9]$ prior to in vitro fertilization (IVF) or intracytoplasmic sperm injection (ICSI). At this stage, removal of the cumulus cells (CCs) from oocytes is often performed. However, studies have reported contradictory results, some of which highlight the beneficial effects of the CCs surrounding the oocyte during vitrification, but others indicate that the presence of these cells decreases CPAs permeability therefore reducing oocyte cryoprotection. CCs play several major roles in oocyte maturation and fertilization [10] and have also been proposed as oocyte quality biomarkers [11]. In this regard, a study reported that vitrified MII oocytes with CCs resulted in higher IVF rates compared to denuded oocytes [12]. It was also reported that the CCs protect MII oocytes against zona pellucida hardening and cytoplasmic damage during vitrification-warming [13]. Additionally, the CCs decrease oocyte cryodamage, preserving their competence for fertilization [14]. These cells are firstly exposed to the CPAs, preventing osmotic shock, facilitating oocyte dehydration, and reducing oocyte damage [13]. Because of this, it was reported that the CCs viability decreases considerably after cumulus-oocyte complexes (COCs) vitrification $[13,15,16]$. In contrast, other studies support that COCs vitrification reduces CPAs penetration and increases ice crystal formation in oocytes leading to inadequate dehydration, which affects oocyte survival $[17,18]$. However, information about the alterations produced by vitrification in porcine CCs is limited.

The inefficiencies in determining the quality of the oocytes are a major issue that compromises successful fertilization rates. Since the direct evaluation of oocytes by means of invasive methods can impair their development, the study of CCs can reflect oocytes developmental competence [19]. Therefore, to evaluate if vitrification is capable of generating DNA damage in the CCs is of great importance for oocyte fertilization and embryo development (ED). For this purpose, DNA fragmentation can be measured by means of the comet assay [20]. Most studies have been carried out to evaluate the effects caused by vitrification on the oocytes leaving aside the importance of the CCs [21, 22, 23]. Stachowiak et al. (2009) [24] evaluated the DNA damage using the comet assay in bovine oocytes exposed to different vitrification methods. This study suggests that the vitrification of MIl oocytes resulted in considerable DNA fragmentation. Also, DNA damage in CCs generated after cryopreservation has been reported in humans $[25,26]$, bovine [27], and equine [4, 13]. It was reported that after vitrification, greater DNA damage is generated in the peripheral CCs than in the inner CCs [4]. However, in pigs, this has not yet been evaluated. Pigs are an important experimental model since this species has anatomical, biochemical, and endocrine similarities with humans [28]. Therefore, in vitro studies may suggest some of the mechanisms of damage produced by vitrification and its possible application in humans. Thus, the evaluation of the DNA integrity after vitrification in CCs will be helpful in order to find new vitrification strategies that will increase IVF and ED rates. Therefore, the aim of this study was to determine if matured porcine COCs exposure to cryoprotectants or vitrification affects both oocyte and cumulus cells viability, and if DNA damage is generated in cumulus cells, affecting fertilization and ED. 


\section{Materials And Methods \\ 2.1 Experimental design}

Seven replicates were performed for all experiments. In vitro matured COCs were randomly distributed into four groups: 1) Control (no treatment); 2) Hydrogen Peroxide ( $\mathrm{H} 囚 \mathrm{O} \mathbb{\text { }}$ ) was used as a DNA damageinducer [29], positive control (COCs exposed to $2.2 \%$ of $\mathrm{H} \otimes \mathrm{O} \otimes$ for $5 \mathrm{~min}$ ); 3 ) Toxicity (COCs exposed to CPAs, EG + DMSO without vitrification); and 4) Vitrification (COCs exposed to CPAs, EG + DMSO and vitrified in Cryolock, Importadora Mexicana de Materiales para Reproducción Asistida S.A. de C.V., México). After treatments, viability was evaluated in oocytes and CCs, and the DNA damage was evaluated only in the CCs. CCs were separated from oocytes by COCs mechanical denudation for evaluation. After treatments, to determine the importance of the CCs during IVF and ED, oocytes were fertilized in the absence (- CCs) or presence (+ CCs) of the CCs. The number of evaluated oocytes and CCs for each experiment is shown in the description of the figure captions.

\subsection{Ethics statement}

This study was approved under the regulations of the Ethics Committee for the care and use of animals; Metropolitan Autonomous University-Iztapalapa Campus.

\subsection{Oocyte collection and in vitro maturation}

Ovaries were collected from pre-pubertal gilts at the "Los Arcos" slaughterhouse (State of Mexico) and transported to the laboratory in $0.9 \% \mathrm{NaCl}$ solution at $25^{\circ} \mathrm{C}$ in less than $2 \mathrm{~h}$. The aforementioned facility has the animal health federal law authorization number 6265375 . Ovarian follicles between 3 and $6 \mathrm{~mm}$ in diameter were punctured to obtain the follicular fluid. Follicular contents were left to sediment and washed twice with Tyrode modified medium supplemented with $10 \mathrm{mM}$ sodium lactate, $10 \mathrm{mM}$ HEPES and $1 \mathrm{mg} / \mathrm{mL}$ polyvinyl alcohol (PVA) (TL-HEPES-PVA) at $\mathrm{pH}$ 7.3-7.4 for COCs collection. Oocytes with uniform cytoplasm surrounded by a two-four-layer compact mass of CCs were selected. COCs were washed three times in $500 \mu \mathrm{L}$ drops of maturation medium: TCM-199 with Earle's salts and $26.2 \mathrm{mM}$ sodium bicarbonate (In Vitro, Mexico) supplemented with 0.1\% PVA, $3.05 \mathrm{mM}$ D-glucose, $0.91 \mathrm{mM}$ sodium pyruvate, $0.57 \mathrm{mM}$ cysteine and $10 \mathrm{ng} / \mathrm{mL}$ EGF, $0.5 \mu \mathrm{g} / \mathrm{mL} \mathrm{LH}$, and $0.5 \mu \mathrm{g} / \mathrm{mL} \mathrm{FSH}$. Oocytes were placed in each well of a four-well dish (Thermo-Scientific Nunc, Rochester NY) containing $500 \mu \mathrm{L}$ of maturation medium and incubated at $38.5^{\circ} \mathrm{C}$ with $5 \% \mathrm{CO}_{2}$ in air and humidity at saturation for $44 \mathrm{~h}$ [7].

\subsection{Cryoprotectants exposure}

After in vitro maturation (IVM), groups of eight to ten COCs were exposed to the highest CPAs concentration solution containing TCM-199, 16\% DMSO, 16\% EG and $0.4 \mathrm{M}$ sucrose at $38.5^{\circ} \mathrm{C}$ for $1 \mathrm{~min}$ (Toxicity group). Immediately, COCs were recovered and washed three times in TL-HEPES-PVA medium. Finally, the comet assay was performed only in CCs. The CPAs concentration, exposure time and temperature were selected to make them comparable to values commonly used for oocyte vitrification protocols [7]. 


\subsection{Vitrification and warming}

After IVM, COCs were exposed to the first vitrification solution containing TCM-199, 7.5\% DMSO and 7.5\% EG for $3 \mathrm{~min}$, and for $1 \mathrm{~min}$ in a second vitrification solution containing TCM-199, 16\% DMSO, 16\% EG and $0.4 \mathrm{M}$ sucrose at $38.5^{\circ} \mathrm{C}$. Groups of eight to ten COCs were loaded into the Cryolock, then immediately plunged horizontally into liquid nitrogen $-196^{\circ} \mathrm{C}$ and stored for $30 \mathrm{~min}$ [7]. For warming, the Cryolock was submerged vertically in a four-well dish containing $800 \mu \mathrm{L}$ of TCM-199 at $38.5^{\circ} \mathrm{C}$ supplemented with $0.13 \mathrm{M}$ sucrose for $5 \mathrm{~min}$. COCs were washed three times in phosphate buffer solution (PBS) and denuded mechanically to obtain only the CCs in order to perform the comet assay.

\subsection{DNA damage in cumulus cells by the comet assay}

The DNA damage generated by CPAs exposure and vitrification in CCs was evaluated by the alkaline comet assay following the protocol by Einaudi et al. (2013) [30]. Results were expressed as Comet Tail Length (CTL) and Olive Tail Moment (OTM), then analyzed with the CromaGen program (ODP, México). Low melting point $(0.5 \%)$ and normal melting point agarose $(0.1 \%)$ were prepared in PBS magnesium salt-free. Frosted slides were covered with normal melting point agarose until solidification at room temperature for at least $24 \mathrm{~h}$. CCs were dissolved in low melting point agarose and added to a slide previously treated with normal melting point agarose in darkness for 10 min until solidification. Another layer of low melting point agarose was added until solidification. Slides were immersed in a lysis solution at $4{ }^{\circ} \mathrm{C}$ for $24 \mathrm{~h}$; then placed in horizontal electrophoresis and equilibrated in the buffer solution for 15 min; afterward, electrophoresis was performed at $25 \mathrm{~V}, 300 \mathrm{~mA}$ for $15 \mathrm{~min}$. After electrophoresis, slides were placed in a neutralization solution for $10 \mathrm{~min}$. Then submerged in 70\% ethanol for $5 \mathrm{~min}$ and, finally, dried at room temperature, for approximately $3 \mathrm{~h}$. To assess DNA damage, slides were stained with $25 \mathrm{~mL}$ of ethidium bromide for 10 min [31] and analyzed using an epifluorescence microscope (Zeiss Axiostar) with the red filter, observing comets at 400X. Comet pictures were analyzed with the CromaGen program, considering the $\mathrm{CTL}$ in micrometers.

\subsection{In vitro fertilization and embryo development}

IVF and ED were carried out following the protocol described by [7]. Briefly, in vitro matured oocytes were washed twice in $500 \mu \mathrm{L}$ of TCM-199 medium and later in $500 \mu \mathrm{L}$ of modified Tris-buffered medium (mTBM). Groups of 30 oocytes from all groups were placed into a four-well dish with $50 \mu \mathrm{L}$ drops of mTBM covered with mineral oil and incubated for $45 \mathrm{~min}$. The semen sample was obtained from one Landrace boar using the gloved hand method at a commercial insemination center, diluted in Duragen (Magapor, México) $1: 2(\mathrm{v}: \mathrm{v})$, then transported to the laboratory at $16^{\circ} \mathrm{C}$ within $2 \mathrm{~h}$ after collection. Sperm motility was evaluated; only semen samples with $>80 \%$ motile spermatozoa were used. For IVF, $5 \mathrm{~mL}$ of the semen sample were diluted with $5 \mathrm{~mL}$ of Dulbecco's phosphate buffered saline (DPBS; In Vitro, S.A., México) medium supplemented with $0.1 \%$ BSA fraction $V, 75 \mu \mathrm{g} / \mathrm{mL}$ potassium penicillin $\mathrm{G}$ and 50 $\mu \mathrm{g} / \mathrm{mL}$ streptomycin sulfate. The suspension was centrifuged (61 $\mathrm{xg}$ for $5 \mathrm{~min}$ ). The pellet was discarded and $5 \mathrm{~mL}$ of the supernatant were diluted 1:1 (v:v) with DPBS and centrifuged (1900 $\mathrm{xg}$ for 5 min). The supernatant was discarded, and the pellet was diluted with $10 \mathrm{~mL}$ of DPBS and centrifuged 
twice under the same conditions. Later, the pellet was diluted in $100 \mu \mathrm{L}$ of mTBM to obtain the final sperm concentration $\left(5 \times 10^{5}\right.$ spermatozoa/mL). After dilution, $50 \mu \mathrm{L}$ of the suspension were added to the medium containing oocytes, and gametes were co-incubated in mTBM for $6 \mathrm{~h}$. After co-incubation, 30 putative zygotes were transferred to four-well dishes containing $500 \mu \mathrm{L}$ drops of North Carolina State University medium (NCSU-23). ED was evaluated under an inverted microscope at $48 \mathrm{~h}$ (2 days post-IVF) and $168 \mathrm{~h}$ (7 days post-IVF).

\subsection{Analysis of the results}

\subsubsection{Evaluation of oocyte maturation, and oocyte and cumulus cells viability}

Maturation was evaluated by the Hoechst stain only in the negative control. Oocytes were stained with 10 $\mu \mathrm{g} / \mathrm{mL}$ bisbenzimide (Hoechst 33342) for 40 min using an epifluorescence microscope (Zeiss Axiostar) 40X for observation. Oocytes with a germinal vesicle (GV) or in metaphase I (MI) were considered immature; and those in MII with the first polar body, as matured.

After treatments, COCs were denuded mechanically and transferred to a $100 \mu \mathrm{L}$ drop of $0.5 \mathrm{mg} / \mathrm{mL}$ methyl-thiazolyl-tetrazolium (MTT) diluted in modified Tris-buffered medium for oocyte viability evaluation. After 90 min, oocytes were observed under a light microscope (Zeiss Axiostar). Oocytes with purple coloration were considered as viable (Fig. 1, A) and colorless ones as non-viable (Fig. 1, B). For CCs viability, another agent was used. $10 \mu \mathrm{L}$ of maturation medium with the CCs were transferred to a 10 $\mu \mathrm{L}$ drop of trypan blue. This $20 \mu \mathrm{L}$ drop was settled in a Neubauer chamber for observation under a light microscope. Colorless cells were considered as viable and those with blue coloration as non-viable (Fig. 1, C-D).

\subsubsection{Evaluation of cumulus cells DNA damage by the comet assay}

The CTL refers to the extent of the DNA damage. The percentage of DNA integrity refers to less DNA damage. Approximately $<15 \mu \mathrm{m}$ of CTL is related to normal or undamaged DNA, and damaged $>30 \mu \mathrm{m}$. The OTM= (\% tail DNA $x$ tail length $) / 100$.

\subsubsection{Evaluation of oocyte fertilization and embryo development}

To evaluate IVF, oocytes were stained with $10 \mu \mathrm{g} / \mathrm{mL}$ bisbenzimide (Hoechst 33,342) diluted in PBS for 40 min. The oocytes were fixed with $2 \%$ glutaraldehyde and mounted in a PBS-glycerol solution (1:9). Putative zygotes were analyzed under an epifluorescence microscope (Zeiss Axiostar) at $400 \mathrm{X}$ magnification. Fertilization was assessed $16 \mathrm{~h}$ after IVF by visualizing pronucleus (PN) formation by the Hoechst staining method. The embryo cleavage (number of zygotes cleaved per total cultivated) and blastocyst rates (number of blastocysts per total cultivated) were determined at $48 \mathrm{~h}$ ( 2 days post-IVF) 
and $168 \mathrm{~h}$ (7 days post-IVF), respectively, by morphological evaluation under an inverted microscope (Olympus-Optical).

\subsection{Statistical analysis}

Seven replicates were performed for all experiments. The data obtained from oocyte and CCs viability, DNA damage in CCs, and oocyte fertilization, cleavage, and blastocyst rates were treated as nonparametric and then analyzed by one-way analyses of variance (ANOVA) followed by a post-hoc multiple comparison Duncan test with a confidence level of $\mathrm{P}<0.05$ using the NCSS ${ }^{11}$ program. Data are presented as Mean \pm SD.

\section{Results}

In the present study, all the oocytes were matured in vitro. Results indicate that the percentage of control oocytes that reached the MII stage was $73 \%$ (Table 1).

\section{Table 1: In vitro maturation of porcine oocytes.}

Porcine oocytes were matured in vitro for $44 \mathrm{~h}$ and Hoechst stain was performed to evaluate oocyte maturation stages in control ( $\mathrm{n}=369$ evaluated oocytes). Oocytes in $\mathrm{GV}$ and $\mathrm{MI}$, were considered immature and oocytes in MII as matured. Data are presented as mean \pm standard deviation (SD). GV= germinal vesicle; $\mathrm{Ml}=$ metaphase $\mathrm{I} ; \mathrm{MII}=$ metaphase II.

\begin{tabular}{|llll|}
\hline \multicolumn{3}{|l|}{ Maturation (mean \pm SD) } & \\
Control & GV & MI & MII \\
\cline { 2 - 4 } & $44 / 369(12 \pm 1.51)$ & $57 / 369(15 \pm 8.81)$ & $268 / 369$ \\
& & & $(73 \pm 8.47)$ \\
\hline
\end{tabular}

\subsection{Oocyte and cumulus cells viability after CPAs exposure and vitrification}

Viability was evaluated in oocytes and CCs after IVM by staining in all groups (Fig. 1; Fig. 2). COCs treated with $\mathrm{H} \otimes \mathrm{O} \otimes$ were used as a positive control. Results demonstrate that viability after EG + DMSO exposure (Toxicity group) and vitrification was significantly lower $\left({ }^{\star} \mathrm{P}<0.05\right)$ in both cell types compared to control (Fig. 2). CCs viability was significantly reduced after vitrification compared to control ( $9 \%$ vs. $89 \%$, respectively). Compared to oocytes, CCs viability decreased significantly in all treatment groups ( ${ }^{\star \star} \mathrm{P}$ $<0.05)$.

\subsection{Cumulus cells DNA damage after CPAs exposure and vitrification}


In the comet assay, fragmented DNA shows the characteristic appearance of a comet tail, while undamaged DNA appears as an intact head. Results demonstrate that higher CTL was obtained in all groups compared to control (Fig. 3; filled circle). Also, results indicate that the percentage of DNA integrity (less DNA damage) was significantly reduced $\left({ }^{*} \mathrm{P}<0.05\right)$ in all groups compared to control (Fig. 3; empty square).

The DNA damage in CCs was also measured using the alkaline comet assay and expressed as OTM. The $\mathrm{OTM}=(\%$ tail DNA $x$ tail length) $/ 100$. In terms of the OTM, results indicate that $\mathrm{H} \mathbb{\mathrm { O }}$, Toxicity, and Vitrification groups were significantly higher $\left({ }^{*} \mathrm{P}<0.05\right)$ than control, demonstrating that higher DNA damage is produced after CPAs exposure and vitrification (Fig. 4; Fig. 5).

\subsection{Oocyte in vitro fertilization and embryo development after CPAs exposure and vitrification in the absence or presence of cumulus cells}

Results demonstrate that oocyte fertilization (72 vs. $81 \%$ ), cleavage (59 vs. $78 \%$ ), and blastocyst rates (14 vs. $21 \%$ ) was significantly higher in granulose-intact oocytes compared to denuded oocytes in control groups ( ${ }^{*} \mathrm{P}<0.05$ ). However, fertilization, cleavage and blastocyst rates significantly decreased in granulose-intact oocytes in the Toxicity and Vitrification groups compared to control (Fig. 6).

\section{Discussion}

The preservation of intact CCs after COCs vitrification is of great importance because these cells play important roles in the maturation and fertilization processes [32, 33]. If the CCs are damaged after vitrification, the further development of the oocyte may be compromised.

\subsection{Oocyte and cumulus cells viability}

Our results demonstrate that CPAs exposure and vitrification decreased oocyte and CCs viability. Also, CCs are more sensitive to vitrification than the oocytes due to the fact that their viability was considerably reduced in comparison with that of the oocytes. In this regard, compared to oocytes, the CCs are smaller in size, and are the first in contact with the CPAs, which implies that high CPAs concentrations are initially received by these cells, making them less cryotolerant [34]. Results obtained in the present study demonstrate that the CCs protected the oocytes during vitrification. It has been widely described that high concentrations of CPAs are toxic and may generate oocyte damage. According to the literature, some studies indicate that a mixture of CPAs decreases their toxicity. In the present study, we used EG + DMSO for vitrification since it has been proven that this mixture allows high survival rates compared to PROH and glycerol in porcine oocytes [35]. Another study with porcine oocytes reported that EG + DMSO and EG + PROH resulted in similar viability and IVM rates after vitrification [36]. Somfai et al. (2015) [2] reported that the mixture of EG + DMSO allows the production of viable blastocysts after immature oocyte vitrification. Also, we previously reported that EG + DMSO resulted in a $30 \%$ blastocyst formation [7]. However, high concentrations of CPAs are still used, promoting detrimental effects in cells, especially 
DNA damage either in the oocytes or the CCs $[13,21,24,25,31,37,38,39]$. For example, it was reported that DMSO inhibits CCs expansion in a concentration-dependent manner, resulting in cell death by apoptosis [40]. Accordingly, the results obtained in the present study indicate that CCs do protect oocytes after vitrification; however, most of them lose their viability. In this regard, other studies reported that the CCs protect and promote cumulus enclosed MII oocyte survival after vitrification in equine [13] and mouse oocytes [34]. Therefore, COCs vitrification preserves oocyte competence. Also, recent strategies for improving vitrification success include the use of a CCs co-culture system [16], the addition of other substances before vitrification, such as cholesterol-loaded methyl-b-cyclodextrin [41], polyvinylpyrrolidone [42], and the modification of equilibrium temperatures [36, 42].

Although viability decreased in CCs, it was also diminished up to $64 \%$ in vitrified MII oocytes. In this regard, the nuclear cell stage before vitrification is a key factor to be considered. GV or MIl oocytes have fewer CPAs and water permeability than zygotes and later-stage embryos [43]. The vitrification of MII oocytes could generate alterations in the plasma membrane, mitochondrial distribution, meiotic spindle, and chromosomes. Rojas et al. (2004) [21] reported that vitrified MIl oocytes show spindle abnormalities because chromosomes are exposed directly to CPAs. In the present study, the reduction of oocyte viability up to $76 \%$ after CPAs exposure and $64 \%$ after vitrification could be due to the possible oocyte injuries caused by the CPAs. Several cryopreservation protocols use a wide variety of CPAs, and it is known that EG has lower permeability compared to DMSO and PROH, but when EG + DMSO are mixed, they display higher permeability than other CPAs preserving oocyte survival $[44,45]$. Therefore, an important relationship between CCs, oocytes, and CPAs permeability might have an impact on COCs survival rates after vitrification. Thus, in this study, it was important to address the knowledge of the alterations caused by vitrification in both, oocytes and CCs.

\subsection{Cumulus cells DNA damage}

For the evaluation of cell genotoxicity caused by CPAs exposure and vitrification, the comet assay has generally been used as an evaluation method. Although many criteria and values have been considered to evaluate DNA damage by means of this technique, most studies consider the CTL as an indicator of the damage extent [46] and the percentage of DNA as fragmentation; however, the OTM is considered the most reliable value [47]. The CTL is related to the percentage of DNA integrity as high CTL values indicate less DNA integrity. In the present study, an alkaline comet assay was performed to detect different types of DNA lesions including single (SSBs) and double-strand breaks (DSBs). However, the alkaline version does not allow simultaneous discrimination between SSBs and DSBs. Then, SSBs represent the most common type of DNA damage and unrepaired SSBs can alter DNA replication and transcription, resulting in diseases [48]. In contrast, DSBs are one of the most severe forms of DNA damage, and can cause cell death, chromosome aberrations or loss of genetic material. Results demonstrate that CPAs exposure and vitrification generated DNA damage in CCs. This damage may be generated due to the fact that the concentrations of CPAs used during vitrification are very high for this cell type. Generally, in most vitrification protocols, these concentrations are calculated considering the characteristics of the oocytes but not those of the CCs. Therefore, this may cause the CCs to suffer more damage by vitrification than 
the oocytes. As reported by Taghizabet et al. (2018) [14], CCs create a natural protective shield around the oocyte against physico-chemical insults due to vitrification. In addition, the DNA damage generated in CCs after vitrification could also be due to the production of reactive oxygen species (ROS) [49]. It was reported that during vitrification, ROS increase and cause detrimental effects. It has been reported that ROS may cause gene and chromosome mutations through DNA DSBs [50]. For example, $\mathrm{H}_{2} \mathrm{O}_{2}$ is believed to cause DNA strand breaks after conversion to the hydroxyl radical [31]. Accordingly, $\mathrm{H}_{2} \mathrm{O}_{2}$ was used in the present study as DNA damage-inducer (positive control). In addition, DMSO cell toxicity has been mainly associated with cell membrane damage. The sulfinyl oxygen binds to water strongly and DMSO can surround polar head groups of cell membranes, which may help explain the compound toxicity [51]. ROS may affect cells integrity, viability and function, contributing to oxidative stress generating mutations and DNA damage [52]. Since it was previously reported that CPAs can increase ROS production and mitochondria are the main endogenous ROS producer, another study reported that DMSO resulted in mitochondria-dependent apoptosis in mouse embryos [53]. Also, oxidative stress could be produced by the disturbance of the cellular redox state or by the accumulation of ROS in cells, which may cause plasma membrane, protein, and DNA damage [53]. The main consequences of a reduction in CCs viability and increased DNA damage are failures in oocyte maturation, fertilization, and embryo production. According to the literature, little is known about the DNA damage generated after vitrification in porcine CCs and most studies only evaluate the cryoinjuries produced in oocytes. In this regard, it was reported that the use of $20 \%$ of EG + DMSO produced DNA damage in porcine vitrified GV oocytes, where $54.8 \%$ of oocytes resulted in DNA damage compared to $5.6 \%$ in the control group [54].

\subsection{Oocyte in vitro fertilization, cleavage, and blastocyst formation}

In porcine oocytes, more studies are needed since ED rates after vitrification are still reported to be low [7, 41]. As mentioned before, the CCs are important for the meiotic resumption and sperm-oocyte recognition prior to fertilization. Results demonstrate that oocyte fertilization, cleavage, and blastocyst rates increase with the presence of the CCs compared to denuded oocytes in control groups. In vitro studies reported that CCs removal decreases fertilization rates in humans [55], and pigs [56]. Also, another study in porcine oocytes reported that the presence of CCs during IVF has a positive influence on ED [57]. In the present study, results demonstrate that the presence of CCs in the toxicity and vitrified groups did not increase fertilization and embryo development rates. This fact could be explained by the decreased CCs viability and the generation of DNA damage after CPAs exposure and vitrification, affecting CCs-sperm recognition prior to fertilization. In this regard, Dos Santos-Neto et al. (2020) [58] suggested to avoid CCs removal before IVF in sheep MII oocytes and the addition of a fresh CCs co-culture system for improving blastocyst production. They reported that vitrification of MII oocytes, fertilized with CC resulted in $22 \%$ cleavage rate, and $9.2 \%$ blastocyst rate. In matured oocytes without CC, cleavage resulted in $15.1 \%$ and blastocyst rate in $4.6 \%$. In the present study with porcine oocytes, we obtained $31 \%$ cleavage (- CCs) and $2 \%$ blastocyst rate (- CCs) compared to $23 \%$ cleavage ( + CCs) and $2 \%$ blastocyst $(+\mathrm{CCs})$. These results were similar to those reported in sheep oocytes; however, differences between species should be 
considered. Therefore, we suggest that the vitrification of porcine mature oocytes should be carried out without removing the CCs since a higher oocyte viability is obtained. However, since viability in the CCs is significantly reduced, the use of a co-culture system with fresh CCs after vitrification could increase IVF and ED rates. In this regard, Dos Santos-Neto et al. (2020) [58] reported that the addition of a co-culture system with CC increases blastocyst rates up to $10.7 \%$ in sheep. Also, it was previously reported that, in the case of vitrified porcine immature oocytes, these cells can be used in co-culture systems improving IVM [16], zygote and blastocyst rates [15, 59].

Gurtovenko \& Anwar (2007) [60] reported the possible mechanism of the interaction of several of the most used CPAs with the lipid bilayer. CPAs are toxic compounds that can damage cell membranes at high concentrations. DMSO has a greater ability to diffuse across the phospholipid bilayer than EG. DMSO at high concentrations (40\%) can destroy cell membranes completely [60]. Another study provides evidence that combining different CPAs in a vitrification solution decreases DMSO toxicity [61]. Additionally, it was previously reported that PG could be used as a substitute for DMSO in vitrification protocols [62]. In agreement with the results obtained in the present study, it was previously reported that the use of EG affects CCs survival after freezing. Surprisingly, even though EG is widely used for embryo cryopreservation, low survival rates in CCs are reported [25]. Therefore, the results obtained in the present study strongly suggest that CCs integrity after CPAs exposure and vitrification is an important factor to be considered for further oocyte developmental competence.

\section{Conclusions}

This study demonstrates that oocyte exposure to CPAs or vitrification reduced viability in both, oocytes and CCs, and generated DNA damage in the CCs, affecting fertilization and ED rates. The decline in oocyte fertilization, cleavage, and blastocyst rates after CPAs exposure or vitrification can be attributed to the reduction in both cell types viability, and the generation of DNA damage in the cumulus cells. These findings will allow to understand some of the mechanisms of oocyte damage after vitrification, and the search for new vitrification strategies to increase fertilization and ED rates.

\section{Abbreviations}

CC

cumulus cells

COCs

cumulus-oocyte complexes

CPAs

cryoprotectant agents

CTL

comet tail length

DMSO

dimethylsulfoxide 
ED

embryo development

EG

ethylene glycol

EGF

epidermal growth factor

GV

germinal vesicle

ICSI

intracytoplasmic sperm injection

IVF

in vitro fertilization

IVM

in vitro maturation

$\mathrm{MI}$

metaphase I

MII

metaphase II

MTT

methyl-thiazolyl-tetrazolium

OTM

olive tail moment

PG

propylene glycol

$\mathrm{PROH}$

1,2-propanediol

PVA

polyvinyl alcohol

ROS

reactive oxygen species

\section{Declarations}

Acknowledgements: The authors wish to thank the "Los Arcos“ slaughterhouse, State of Mexico for the donation of porcine ovaries.

Author contributions: Conception and design of the study: $A L, M B, Y D$, and FC; Direction of the experiments: MB and FC; Technical assistance: JJR; Execution of experiments: AL and FC; Data analysis: $A L, M B, E C$, and FC; Manuscript writing: AL and FC; Manuscript revision: JJR, EC, EB, IB, SRM, and LJR. All authors revised, discussed, read, and approved the manuscript for publication. 
Funding: This study was financially supported by CONACyT, grant number: 598630 to Alma López for Ph.D. in Biological Health and Sciences.

Availability of data and materials: Not applicable

Ethics approval and consent to participate: This study was performed under the Ethics Committee regulations for the care and use of animals; Metropolitan Autonomous University-Iztapalapa Campus

Competing interests: The authors declare no competing interests.

\section{References}

1.- Wei-Tung $\mathrm{H}$, Wolfgang $\mathrm{H}$. Effects of meiotic stages, cryoprotectants, cooling and vitrification on the cryopreservation of porcine oocytes. Asian-Aust Journal of Animal Sciences. 2002;4:485-493. DOI: $10.5713 /$ ajas. 2002.485

2.- Somfai T, Men NT, Noguchi J, Kaneko H, Kashiwazaki N, Kikuchi K. Optimization of cryoprotectant treatment for the vitrification of immature cumulus-enclosed porcine oocytes: comparison of sugars, combinations of permeating cryoprotectants and equilibration regimens. Journal Reproduction \& Development. 2015;61:571-579. DOI: 10.1262/jrd.2015-089

3.- Wang M, Isachenko E, Todorov P, Rahimi G, Mallmann P, Katkov I, et al. Aseptic technology for cryoprotectant-free vitrification of human spermatozoa by direct dropping into clean liquid air: apoptosis, necrosis, motility and viability. BioMed Research International. 2020;2934315. 10.1155/2020/2934315

4.- Pereira BC, Ortiz I, Dorado JM, Diaz-Jimenez A, Consuegra C, Gosalvez J, et al. Effect of permeable cryoprotectants-free vitrification on DNA fragmentation of equine oocyte-cumulus cells. Reproduction in Domestic Animals. 2019;3:53-56. DOI: 10.1111/rda.13491

5.- Isachenko V, Todorov P, Seisenbayeva A, Toishibekov Y, Isachenko E, Rahimi G, et al. Vitrification of human pronuclear oocytes by direct plunging into cooling agent: Non sterile liquid nitrogen vs. sterile liquid air. Cryobiology. 2018;80:84-88. DOI: 10.1016/j.cryobiol.2017.11.009

6.- Szurek EA, Eroglu A. Comparison and avoidance of toxicity penetrating cryoprotectants. Plos One. 2011;6:e27604. DOI: 10.1371/journal.pone.0027604

7.- Casillas F, Betancourt M, Cuello C, Ducolomb Y, López A, Juárez-Rojas L, et al. An efficiency comparison of different in vitro fertilization methods: IVF, ICSI and PICSI for embryo development to the blastocyst stage from vitrified porcine immature oocytes. Porcine Health Management. 2018;4:16. DOI: $10.1186 / \mathrm{s} 40813-018-0093-6$

8.- Mullen SF, Fahy GM. A chronologic review of mature oocyte vitrification research in cattle, pigs, and sheep. Theriogenology. 2012;78:1709-1719. DOI: 10.1016/j.theriogenology.2012.06.008 
9.- Clark NA, Swain JE. Oocyte cryopreservation: searching for novel improvement strategies. Journal of Assisted Reproduction Genetics. 2013;30:865-875. DOI: 10.1007/s10815-013-0028-8

10.- Van Soom A, Tanghe S, De Pauw I, Maes D, De Kruif A. Function of the cumulus oophorus before and during mammalian fertilization. Reproduction in Domestic Animals. 2002;37:144-151. DOI:

10.1046/j.1439-0531.2002.00345.x

11.- Ekart J, McNatty K, Hutton J, Pitman J. Ranking and selection of MIl oocytes in human ICSI cycles using gene expression levels from associated cumulus cells. Human Reproduction. 2013;28:2930-2942. DOI: 10.1093/humrep/det357

12.- Kohaya N, Fujiwara K, Ito J, Kashiwazaki N. High developmental rates of mouse oocytes cryopreserved by an optimized vitrification protocol: the effects of cryoprotectants, calcium and cumulus cells. Journal Reproduction \& Development. 2011;57:675-680. DOI: 10.1262/jrd.11-066h

13.- Tharasanit T, Colleoni S, Galli C, Colenbrander B, Stout A. Protective effects of the cumulus-corona radiata complex during vitrification of horse oocytes. Reproduction. 2009;137:391-401. DOI:

10.1530/REP-08-0333

14.- Taghizabet N, Ali Khalili M, Anbari F, Agha-Rahimi A, Nottola SA, Macchiarelli G, et al. Human cumulus cell sensitivity to vitrification, an ultrastructural study. Zygote. 2018;26:224-231. DOI: $10.1017 /$ S0967199418000138

15.- Jin HX, Song WY, Xin ZM, Dai SJ, Chen ZJ, Sun YP. Effects of cumulus cells on vitreous cryopreservation of human mature oocytes and clinical pregnancy outcomes. Reproductive Sciences. 2012;19:216-220. DOI: 10.1177/1933719111424450

16.- Casillas F, Teteltitla-Silvestre M, Ducolomb Y, Lemus AE, Salazar Z, Casas E, et al. Co-culture with granulosa cells improve the in vitro maturation ability of porcine immature oocytes vitrified with cryolock. Cryobiology. 2014;69:299-304. DOI: 10.1016/j.cryobiol.2014.08.004

17.- Gook DA, Osborn SM, Johnston WI. Cryopreservation of mouse and human oocytes using 1,2propanediol and the configuration of the miotic spindle. Human Reproduction. 1993;8:1101-1109. DOI: 10.1093/oxfordjournals.humrep.a138201

18.- Ortiz-Escribano N, Smits K, Piepers S, Van den Abbeel E, Woelders H, Van Soom A. Role of cumulus cells during vitrification and fertilization of mature bovine oocytes: Effects on survival, fertilization, and blastocyst development. Theriogenology. 2016;86:635-641. DOI: 10.1016/j.theriogenology.2016.02.015

19.- Su YQ, Sugira K, Eppig JJ. Mouse oocyte control of granulosa cell development and function: paracrine regulation of cumulus cell metabolism. Seminars in Reproductibe Medicine. 2009;27:32-42. DOI: $10.1055 / \mathrm{s}-0028-1108008$ 
20.- Lorenzo Y, Costa S, Collins AR, Azqueta A. The comet assay, DNA damage, DNA repair and cytotoxicity: hedgehogs are not always dead. Mutagenesis. 2013;28:427-432. DOI:

10.1093/mutage/get018

21.- Rojas C, Palomo MJ, Albarracín JL, Mogas T. Vitrification of immature and in vitro matured pig oocytes: study of distribution of chromosomes, microtubules and actin microfilaments. Cryobiology. 2004;49:211-220. DOI: 10.1016/j.cryobiol.2004.07.002

22.- Brambillasca F, Guglielmo MC, Coticchio G, Mignini Renzini M, Dal Canto M, Fadini R. The current challenges to efficient immature oocyte cryopreservation. Journal of Assisted Reproduction Genetics. 2013;30:1531-1539. DOI: 10.1007/s10815-013-0112-0

23.- Lei T, Guo N, Liu JQ, Tan MH, Li YF. Vitrification of in vitro matured oocytes: effects on meiotic spindle configuration and mitochondrial function. International Journal of Clinical \& Experimental Pathology. 2014;7:1159-1165. DOI: PMID: 24696732

24.- Stachowiak EM, Papis K, Kruszewski M, Iwanenko T, Bartlomiejczyk T, Modlinski JA. Comparison of the level(s) of DNA damage using comet assay in bovine oocytes subjected to selected vitrification methods. Reproduction in Domestic Animals. 2009;44:653-658. DOI: 10.1111/j.1439-0531.2007.01042.x

25.- Lindley EM, Jacobson JD, Corselli J, King A, Chan PJ. Cryopreservation of human cumulus cells for co-cultures and assessment of DNA damage after thawing using the comet assay. Journal of Assisted Reproduction \& Genetics. 2001;18:534-538. DOI: 10.1023/A:1011991806423

26.- Raman RS, Chan PJ, Corselli JU, Patton WC, Jacobson JD, Chan SR, et al. Comet assay of cumulus cell DNA status and the relationship to oocyte fertilization via intracytoplasmic sperm injection. Human Reproduction. 2001;16:831-835. DOI: 10.1093/humrep/16.5.831

27.- Urrego R, Pareja A, Vásquez N, Márquez M. El ensayo cometa: una técnica para evaluar genotoxicidad en el ADN de ovocitos bovinos. Revista Colombiana Ciencias Pecuarias. 2005;18:222-227. ISSN: 2256-2958

28.- Petters RM. Transgenic livestock as genetic models of human dis- ease. Reproduction, Fertility, and Development. 1994;6:643-645. DOI: https://doi. org/10.1071/rd9940643

29.- Collins AR, El Yamani N, Lorenzo Y, Shaposhnikov S, Brunborg G, Azqueta A. Controlling variation in the comet assay. Frontiers in Genetics. 2014;20:5:359. DOI: 10.3389/fgene.2014.00359

30.- Einaudi L, Courbiere B, Tassistro V, Prevot C, Sari-Minodier I, Orsiere T, et al. In vitro exposure to benzo(a)pyrene induces significant DNA damage in mouse oocytes and cumulus cells. Human Reproduction. 2013;29:548-554. DOI: https://doi.org/10.1093/humrep/det439

31.- Berthelot-Ricou A, Perrin J, Di Giorgio C, De Meo M, Botta A, Courbiere B. Comet assay on mouse oocytes: an improved technique to evaluate genotoxic risk on female germ cells. Fertility \& Sterility. 
32.- Racowsky C, Needleman DJ. Cumulus cell gene expression as a potential biomarker for oocyte quality. Fertility \& Sterility. 2018;109:438-439. DOI: 10.1016/j.fertnstert.2017.12.013

33.- Casillas F, Ducolomb Y, López A, Betancourt M. Effect of porcine immature oocyte vitrification on oocyte-cumulus cell gap junctional intercellular communication. Porcine Health Management. 2020;6:37. DOI: 10.1186/s40813-020-00175-x.

34.- Cheng-Jie Z, Dong-Hui W, Xin-Xin N, Xiang-Wei K, Yan-Jiao L, Jing R, et al. High survival of mouse oocytes using an optimized vitrification protocol. Scientific Reports. 2016;6:19465. DOI:

10.1038/srep19465

35.- Cuello C, Sanchez-Osorio J, Almiñana C, Gil MA, Parrilla I, Roca J, Vazquez JM, et al. Superfine open pulled straws vitrification of porcine blastocysts does not require pretreatment with cytochalasin $B$ and/or centrifugation. Reproduction Fertility \& Devoplment. 2010;28:808-817. DOI: 10.1071/RD09160

36.- Wu G, Jia B, Quan G, Xiang D, Zhang B, Shao Q, et al. Vitrification of porcine immature oocytes: association of equilibration manners with warming procedures, and permeating cryoprotectants effects under two temperatures. Cryobiology. 2017;75:21-27. DOI: 10.1016/j.cryobiol.2017.03.001

37.- Berthelot-Ricou A, Perrin J, Di Giorgio C, De Meo M, Botta A, Courbiere B. Genotoxicity assessment of mouse oocytes by comet assay before vitrification and after warming with three vitrification protocols. Fertility \& Sterility. 2013;100:882-888. DOI: 10.1016/j.fertnstert.2013.05.025

38.- Berthelot-Ricou A, Perrin J, Orsière T, Aye M, Roustan A, Botta A, et al. Genotoxicity risk assessment and oocytes: Basis of genetic toxicology and application in reproductive science. Gynecologie Obstetrique \& Fertilite. 2013;41:544-547. DOI: 10.1016/j.gyobfe.2013.07.008

39.- Kopeika J, Thornhill A, Khalaf Y. The effect of cryopreservation on the genome of gametes and embryos: principles of cryobiology and critical appraisal of the evidence. Human Reproduction Update. 2015;21:209-227. DOI: 10.1093/humupd/dmu063

40.- Li X, Wang YK, Song ZQ, Du ZQ, Yang CX. Dimethyl sulfoxide perturbs cell cycle progression and spindle organization in porcine meiotic oocytes. Plos One. 2016;11:e0158074. DOI:

10.1371/journal.pone.0158074

41.- Chen X, Dong H, Cheng M, Wang Q, Jin Y. Addition of cholesterol loaded cyclodextrin prior to GVphase vitrification improves the quality of mature porcine oocytes in vitro. Cryobiology. 2019;90:54-62. DOI: 10.1016/j.cryobiol.2019.08.006

42.- Appeltant R, Somfai T, Kikuchi K. Faster, cheaper, defined and efficient vitrification for immature porcine oocytes through modification of exposure time, macromolecule source and temperature. Cryobiology. 2018;85:87-94. DOI: 10.1016/j.cryobiol.2018.09.004 
43.- Kharche SD, Sharma GT, Majumdar AC. In vitro maturation and fertilization of goat oocytes vitrified at the germinal vesicle stage. Small Ruminant Research. 2005;57:81-84. DOI:

10.1016/j.smallrumres.2004.03.003

44.- Agca Y, Liu J, Peter AT, Crister ES, Crister JK. Effect of developmental stage on bovine oocyte plasma membrane water and cryoprotectant permeability characteristics. Molecular Reproduction \& Development. 1998;49:408-415. DOI: 10.1002/(SICI)1098-2795(199804)49:4<408::AID-MRD8>3.0.C0;2-R

45.- Cuello C, Sánchez-Osorio J, Almiñana C, Gil MA, Perals ML, Lucas X, et al. Effect of the cryoprotectant concentration on the in vitro embryo development and cell proliferation of OPS-vitrified porcine blastocysts. Cryobiology. 2008;56:189-194. DOI: 10.1016/j.cryobiol.2008.02.005

46.- Gunasekarana V, Raj GB, Chand P. A comprehensive review on clinical applications of comet assay. Journal of Clinical and Diagnostic Research. 2015;9:GE01-GE05. DOI: 10.7860/JCDR/2015/12062.5622

47.- Greco F, Perrin J, Auffan M, Tassistro V, Orsiere T, Courbiere B. A new approach for the oocyte genotoxicity assay: adaptation of comet assay on mouse cumulus-oocyte complexes. Laboratory Animals. 2015;49:251-254. DOI: 10.1177/0023677214567136

48.- Hossain MDA, Lin Y, Yan S. Single-strand break end resection in genome integrity: mechanism and regulation by APE2. International Journal Molecular Science. 2018;19:2389. DOI: 10.3390/ijms19082389

49.- Somfai T, Ozawa M, Noguchi J, Kaneko H, Karja NWK, Farhudin M, et al. Developmental competence of in vitro-fertilized porcine oocytes after in vitro maturation and solid surface vitrification: effect of cryopreservation on oocyte antioxidative system and cell cycle stage. Cryobiology. 2007;55:115-126. DOI: 10.1016/j.cryobiol.2007.06.008

50.- Sharma V, Collins LB, Chen TH, Herr N, Takeda S, Sun W, et al. Oxidative stress at low levels can induce clustered DNA lesions leading to NHEJ mediated mutations. Oncotarget. 2016;7:25377-25390. DOI: $10.18632 /$ oncotarget.8298

51.- Best BP. Cryoprotectants toxicity: facts, issues and questions. Rejuvenation Research. 2015;18:422436. DOI: $10.1089 /$ rej.2014.1656

52.- Goud AP, Goud PT, Diamond MP, Gonik B, Abu-Soud HM. Reactive oxygen species and oocyte aging: role of superoxide, hydrogen peroxide and hypochlorous acid. Free Radical Biology and Medicine. 2008;44:1295-1304. DOI: 10.1016/j.freeradbiomed.2007.11.014

53.- Kang MH, Das J, Gurunathan S, Park HW, Song H, Park C, et al. The cytotoxic effects of dimethyl sulfoxide in mouse preimplantation embryos: a mechanistic study. Theranostics. 2017;7:4735-4752. DOI: $10.7150 /$ thno. 21662

54.- Taniguchi M, Agung B, Morita Y, Sato Y, Otoi T. Meiotic competence and DNA damage of porcine immature oocytes following cryoprotectant exposure and vitrification. Asian Joutnal of Animal and 
55.- Xian-Hong T, Li-Min W, Ren-Tao J, Li-Hua L, Hong-Bing L, Yu-Sheng L. Fertilization rates are improved after IVF if the corona radiate is left intact in vitrified-warmed human oocytes. Human Reproduction. 2012;27:3208-3214. DOI: 10.1093/humrep/des295

56.- Suzuki K, Eriksson B, Shimizu H, Nagai T, Rodríguez-Martinez H. Effect of hyaluronan on monospermic penetration of porcine oocytes fertilized in vitro. International Journal of Andrology. 2000;23:13-21. DOI: 10.1046/j.1365-2605.2000.t01-1-00198.x

57.- Wongsrikeao P, Kaneshige $\mathrm{Y}$, Ooki R, Taniguchi M, Agung B, Nii M, et al. Effect of the removal of cumulus cells on the nuclear maturation, fertilization and development of porcine oocytes. Reproduction in Domestic Animals. 2005;40:166-170. DOI: 10.1111/j.1439-0531.2005.00576.x

58.- Dos Santos-Neto PC, Vilariño M, Cuadro F, Barrera N, Crispo M. Cumulus cells during in vitro fertilization and oocyte vitrification in sheep: Remove, maintain ir add?. Cryobiology. 2020;92:161-167. DOI: $10.1016 /$ j.cryobiol.2020.01.002

59.- Casillas F, Ducolomb Y, Lemus AE, Cuello C, Betancourt M. Porcine embryo production following in vitro fertilization and intracytoplasmic sperm injection from vitrified immature oocytes matured with a granulosa cell co-culture system. Cryobiology. 2015;71:299-305. DOI: 10.1016/j.cryobiol.2015.08.003

60.- Gurtovenko AA, Anwar J. Modulating the structure and properties of cell membranes: the molecular mechanism of action of dimethyl sulfoxide. Journal of Physical Chemistry B. 2007;111:10453-10460. DOI: $10.1021 /$ jp073113e

61.- Hughes ZE, Mancera RL. Molecular mechanism of the synergistic effects of vitrification solutions on the stability of phospholipid bilayers. Biophys Journal. 2014;106:2617-2624. DOI:

10.1016/j.bpj.2014.05.012

62.- Malajczuk CJ, Hughes ZE, Mancera RL. Molecular dynamics simulation of the interactions of DMSO, mono- and polyhydroxylated cryosolvents with a hydrated phospholipid bilayer. Biochimica et Biophysica Acta. 2013;1828:2041-2055. DOI: 10.1016/j.bbamem.2013.05.010

\section{Figures}




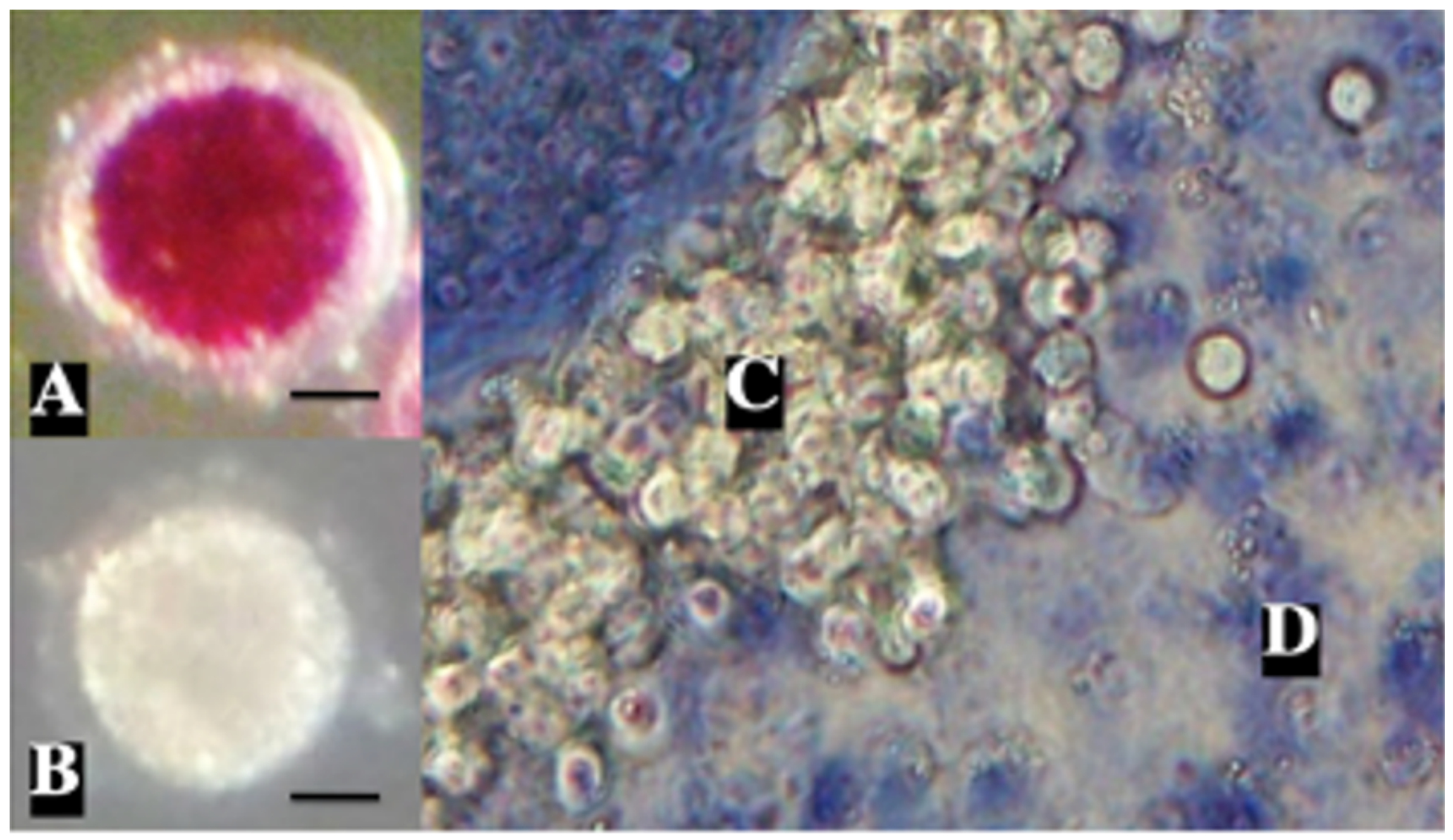

\section{Figure 1}

Viability evaluation in oocytes and cumulus cells. Representative images from oocytes (A-B) and cumulus cells $(C-D)$ for viability evaluation in different groups at 40X. Oocyte $(n=304)$ and cumulus cells $(n=400)$ viability was evaluated after $44 \mathrm{~h}$ of in vitro maturation. For oocytes and cumulus cells, different staining agents were used: methyl-thiazolyl-tetrazolium (MTT) and methylene blue, respectively. A) Stained purple oocyte: alive; B) Unstained oocyte: dead; C) Unstained cumulus cells: alive; D) Stained cumulus cells: dead. Scale bar: $30 \mu \mathrm{m}$. $\mathrm{n}=$ number of evaluated cells. 


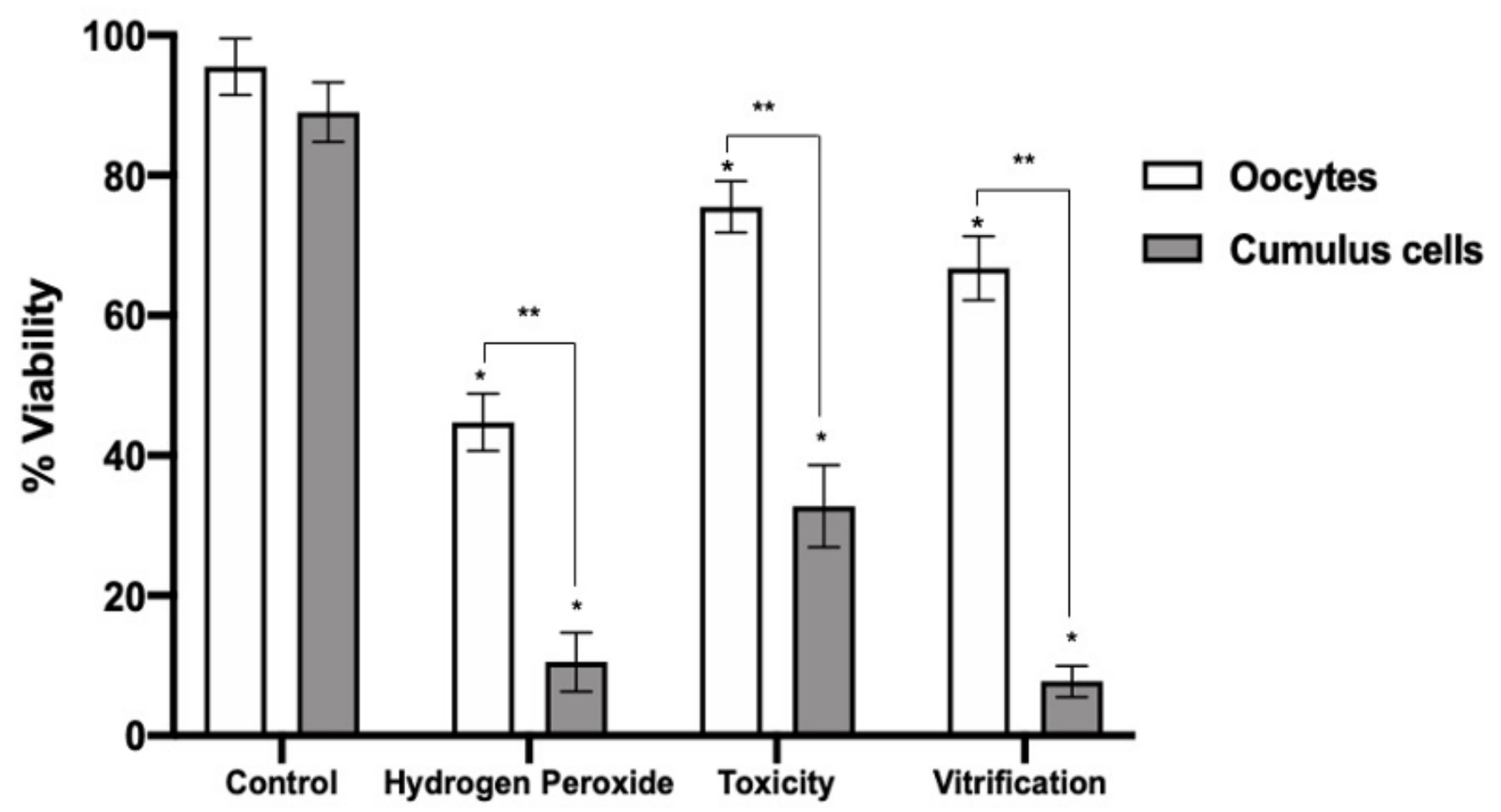

Figure 2

Percentage of oocyte and cumulus cells viability. Hydrogen peroxide (COCs exposed to $2.2 \% \mathrm{H} 2 \mathrm{O} 2$ ), Toxicity (16\% EG + DMSO), and Vitrification (EG + DMSO + Vitrification). Cumulus cells (CCs) were removed from oocytes $(n=304)$ for evaluation. Control $(n=242$ evaluated CCs), H2O2 ( $n=263$ evaluated CCs), Toxicity ( $n=204$ evaluated CCs), Vitrification ( $n=219$ evaluated CCs). In all groups, decreased viability was observed in both cell types compared to control. Compared to oocytes, CCs viability decreased significantly in all groups. Data are presented as mean \pm standard deviation (SD). Significant differences were considered when $\mathrm{P}<0.05$. * Indicates significant difference vs. control. ** Indicates significant difference between oocytes and cumulus cells. $\mathrm{H} 2 \mathrm{O} 2=$ hydrogen peroxide; $\mathrm{EG}=$ ethylene glycol; DMSO $=$ dimethylsulphoxide. $n=$ number of evaluated cells. 


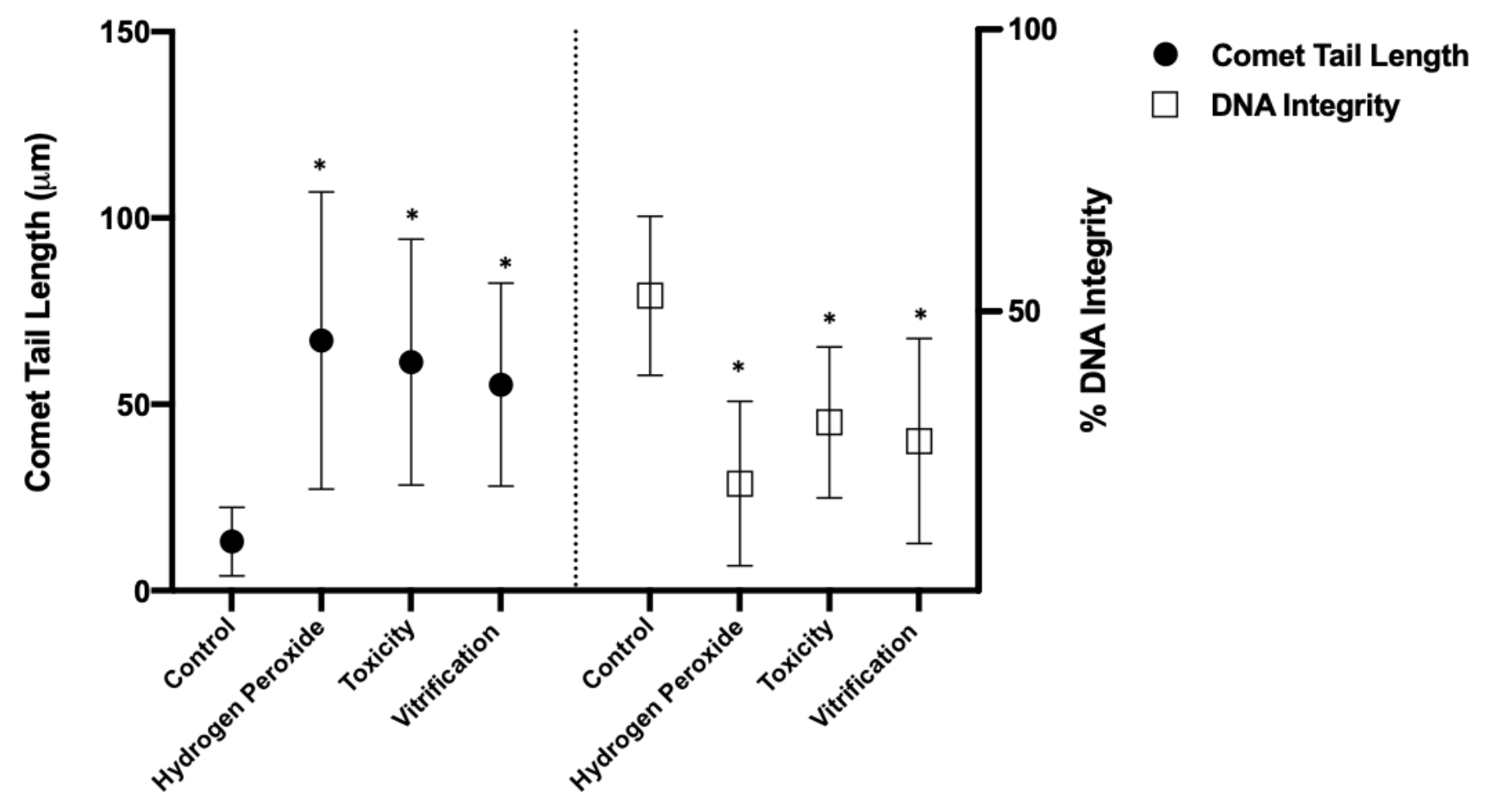

Figure 3

Cumulus cells genotoxicity assessment by the comet assay expressed by the Comet Tail Length (CTL) and DNA Integrity. Hydrogen peroxide (COCs exposed to $2.2 \% \mathrm{H} 2 \mathrm{O} 2$ ), Toxicity (16\% EG + DMSO), and Vitrification (EG + DMSO + Vitrification). Cumulus cells (CCs) were removed from oocytes for evaluation. Control ( $n=242$ evaluated CCs), H2O2 ( $n=263$ evaluated CCs), Toxicity ( $n=204$ evaluated CCs), Vitrification ( $n=219$ evaluated CCs). The CTL refers to the extent of DNA damage, and DNA integrity to the percentage of DNA in the comet's head (no DNA damage). Approximately $<15 \mu \mathrm{m}$ of CTL is related to normal or undamaged DNA, and damaged $>30 \mu \mathrm{m}$. Higher CTL and lower DNA integrity was obtained in all groups compared to control. Data are presented as mean \pm standard deviation (SD). Significant differences were considered when $\mathrm{P}<0.05$. * Indicates significant difference vs. control. CTL= comet tail length; $\mathrm{H} 2 \mathrm{O} 2=$ hydrogen peroxide; $\mathrm{EG}=$ ethylene glycol; $\mathrm{DMSO}=$ dimethylsulphoxide . 


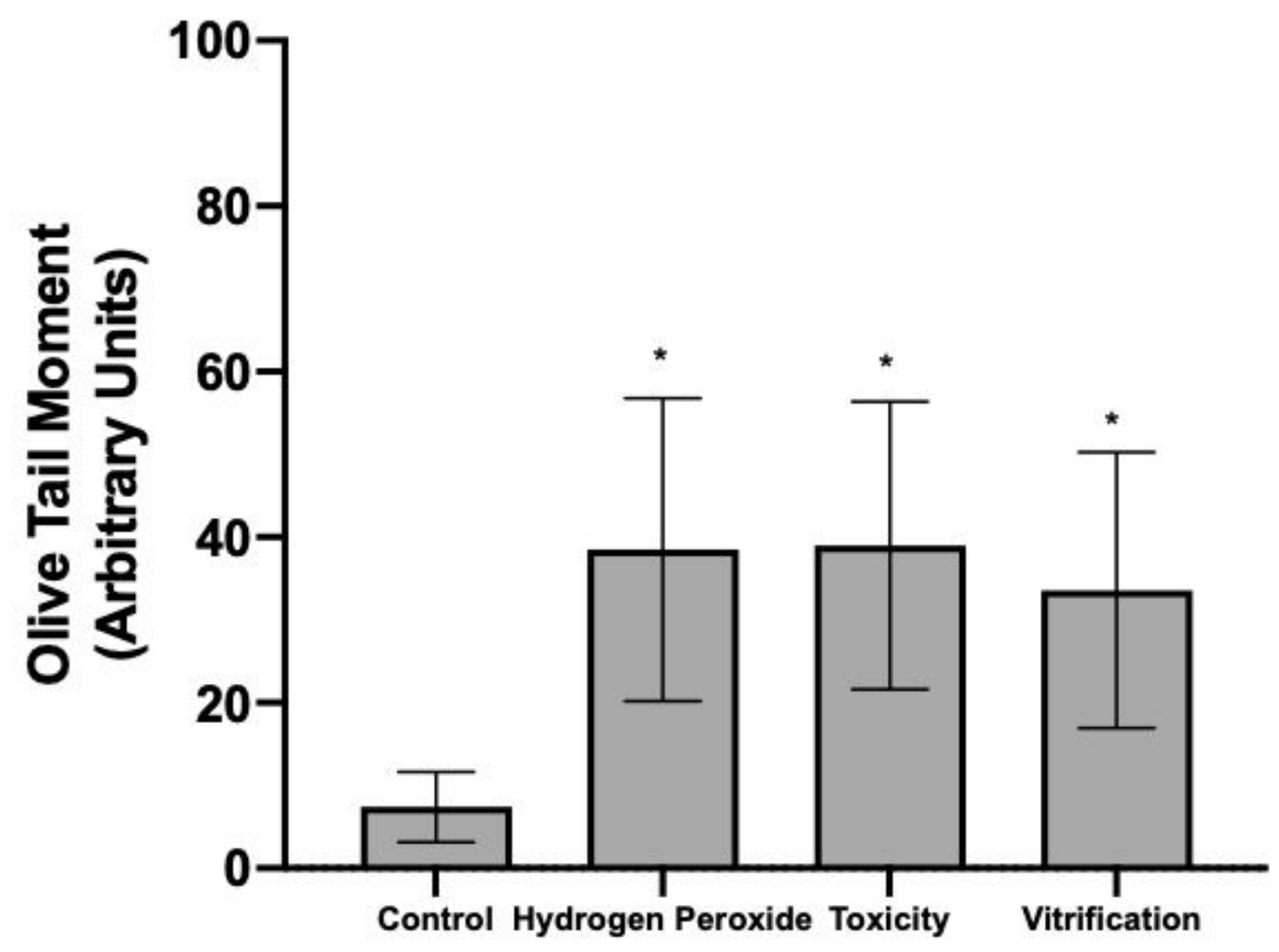

Figure 4

Cumulus cells genotoxicity assessment by the comet assay expressed by the Olive Tail Moment (OTM). Hydrogen peroxide (COCs exposed to $2.2 \%$ H2O2), Toxicity (16\% EG + DMSO), and Vitrification (EG + DMSO + Vitrification). Cumulus cells (CCs) were removed from oocytes for evaluation. Control $(n=242$ evaluated CCs), H2O2 ( $n=263$ evaluated CCs), Toxicity ( $n=204$ evaluated CCs), Vitrification ( $n=219$ evaluated CCs). The OTM represents the product of the percentage of total DNA in the tail and the distance between the centers of the head and tail regions. High OTM value indicates DNA damage. Higher OTM values were obtained in all groups compared to control. Data are presented as arbitrary units. Significant differences were considered when $\mathrm{P}<0.05$. * Indicates significant difference vs. control. $\mathrm{OTM}=$ olive tail moment; $\mathrm{H} 2 \mathrm{O} 2=$ hydrogen peroxide; $\mathrm{EG}=$ ethylene glycol; $\mathrm{DMSO}=$ dimethylsulphoxide . 


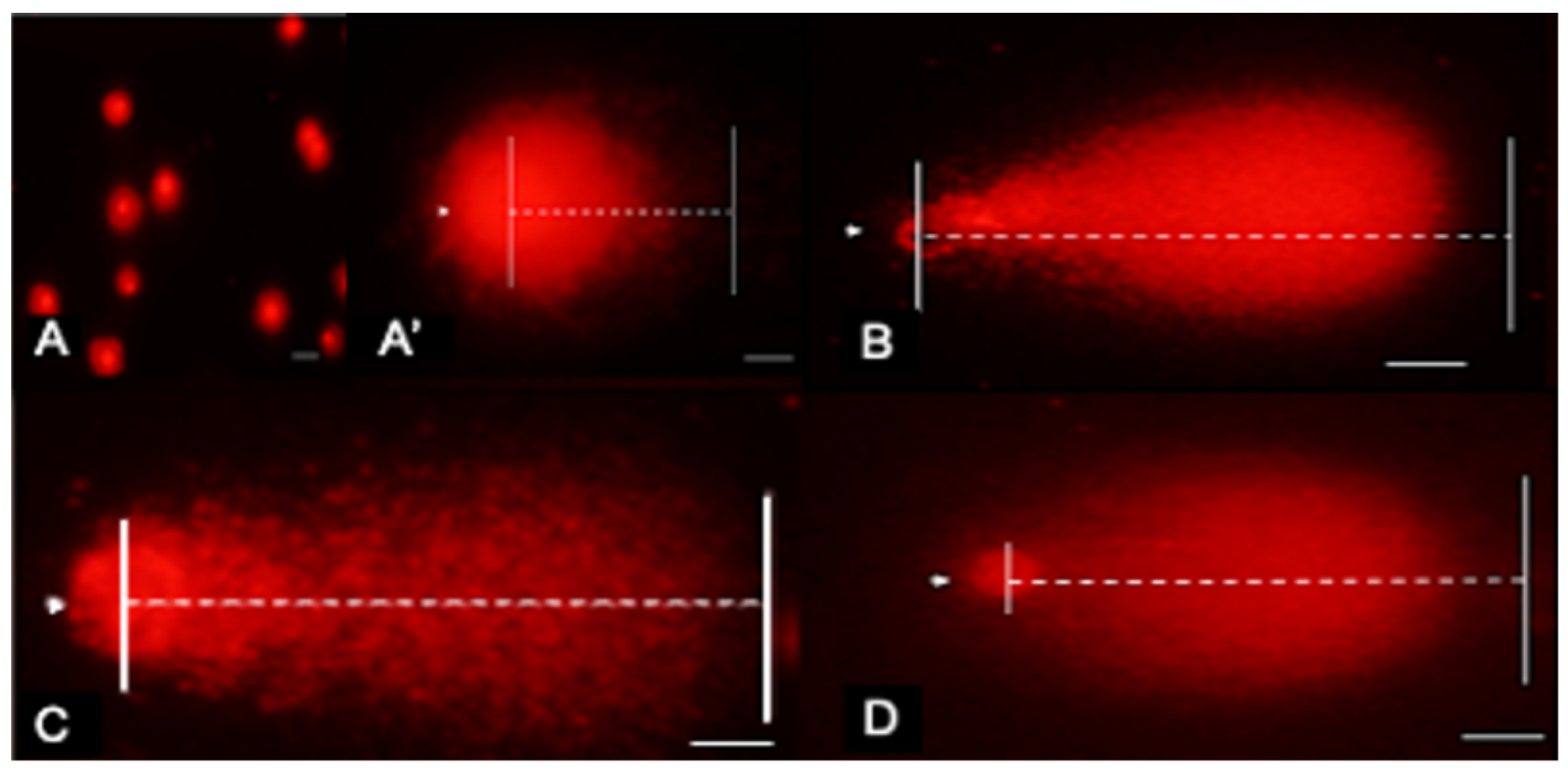

\section{Figure 5}

Cumulus cells comet assay evaluation. Representative images of comet assay evaluation. The direction of electrophoresis was left to right, and DNA fragments are observed as a comet tail. A) Cumulus cells control magnification at 200X; no DNA migration. Scale bar: $15 \mu \mathrm{m}$. $\mathrm{A}^{\prime}$ ) Cumulus cells control: one cell magnification at 400X; no DNA migration. Scale bar: $15 \mu \mathrm{m}$. B) Cumulus cells exposed to $\mathrm{H} 2 \mathrm{O} 2$ magnification at 400X; DNA migration. Scale bar: $15 \mu \mathrm{m}$. C) Cumulus cells exposed to EG + DMSO magnification at 400X; DNA migration. Scale bar: $15 \mu \mathrm{m}$. D) Cumulus cells EG + DMSO + Vitrification group magnification at 400X; DNA migration. Dotted line indicates the CTL and the arrowhead the nucleoid of the cumulus cell. The percentage of DNA integrity is presented as less DNA damage, shown in $A$ and $A^{\prime}$ pictures. 


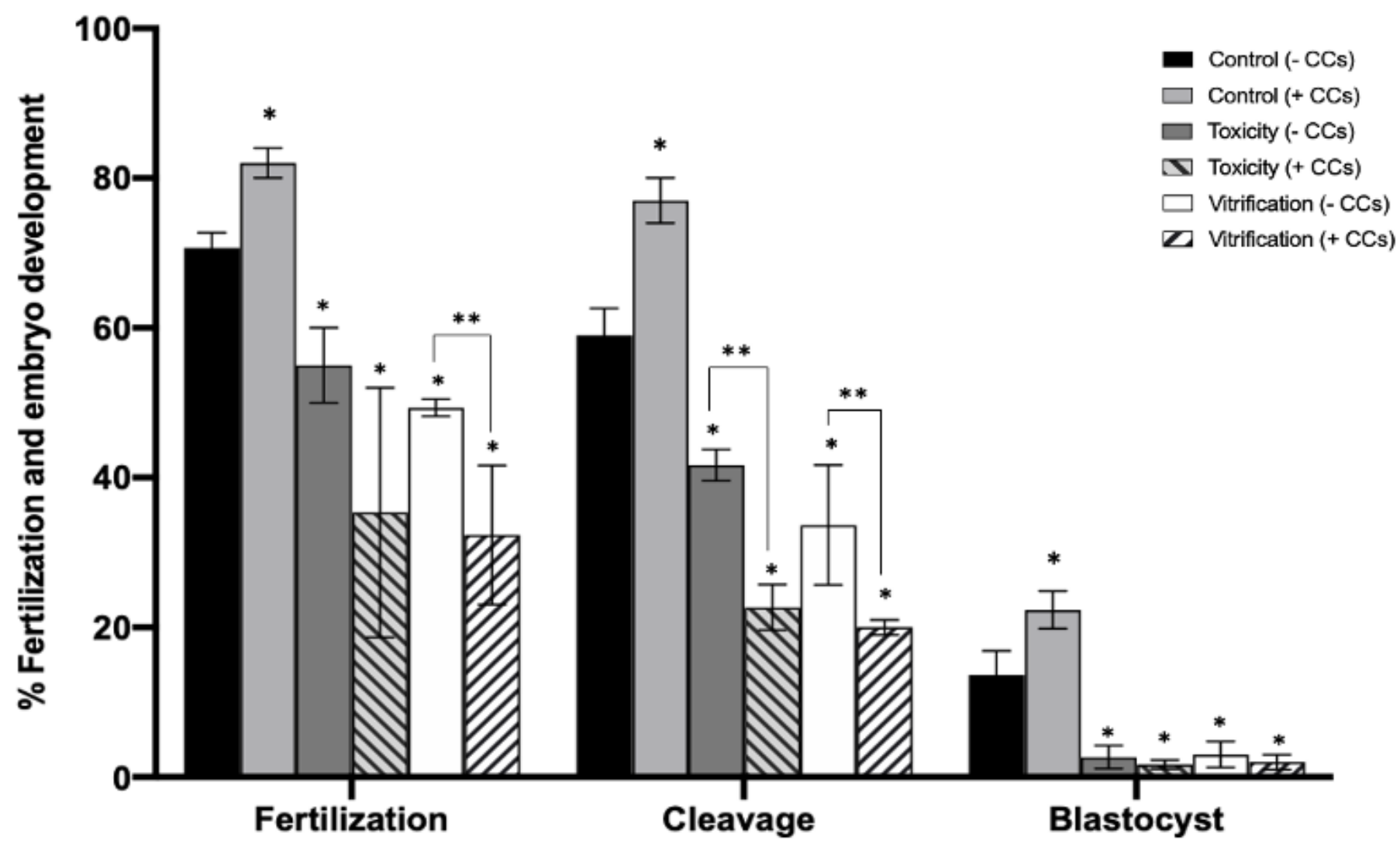

Figure 6

In vitro fertilization, cleavage, and blastocyst rates evaluation. Toxicity (16\% EG + DMSO), and Vitrification (EG + DMSO + Vitrification). After treatments, to determine the importance of the cumulus cells during fertilization and embryo development, oocytes were fertilized in the absence (- CCs) or presence (+ CCs) of the CCs. The number of evaluated oocytes/treatment was $n=214$. Oocyte fertilization, cleavage, and blastocyst rates increased significantly with the presence (+ CCs) of CCs compared to denuded oocytes in control groups. However, fertilization, cleavage and blastocyst rates significantly decreased in the Toxicity and Vitrification groups. Also, the presence of CCs in the toxicity and vitrification groups did not increase fertilization, cleavage, and blastocyst rates compared to control. Data are presented as mean \pm standard deviation (SD). Significant differences were considered when $\mathrm{P}<$ 0.05. * Indicates significant difference vs. the respective control. **Indicates significant difference between treatments. $\mathrm{EG}=$ ethylene glycol; $\mathrm{DMSO}=$ dimethylsulphoxide. $\mathrm{n}=$ number of evaluated cells. 